\title{
Homes across the Border: Russian Summer Houses in the Karelian Isthmus and the Finnish State, 1917-1927
}

Kitty Lam*

\begin{abstract}
At the end of the $19^{\text {th }}$ century, numerous St. Petersburg residents established their summer homes in the Karelian Isthmus, a picturesque region in the Grand Duchy of Finland, an autonomous province of the Russian Empire. The ease of travel between the Russian imperial capital and the Finnish seaside towns contributed to this practice. After 1917, a new border regime delineated the nascent Finnish state from the equally new Russian/ Soviet state. This change displaced the majority of Russian proprietors, as well as those imperial subjects who rented vacation properties from local Finns. This article addresses how state-building practices distinguishing between insiders' and outsiders' access to rights and privileges reflected the significance of territorial borders as markers of a state's territorial sovereignty. It does so by investigating how Finnish-Russian social ties affected the Finnish government's management of real estate owned or used by subjects of the former Russian Empire. Using archival material from the Administrative Organ for Property of Foreign Owners in Viipuri Province (Finland), this article examines how property settlements decisions had unintended consequences when officials attempted to balance state and individual interests. These decisions in turn challenged the primacy of the territorial border as an institution that separates insiders from outsiders.
\end{abstract}

\section{Introduction}

In the 1910s, Aino Väisänen's family regularly sold produce to Russians who visited their summer homes in Finnish villages located near the Finnish-Russian border. After 1917, changes to this border regime created obstacles for Russians, whose legal status in Finland was now in limbo, who wished to keep their properties in Finland. Aino's father arranged to pay property taxes on behalf of the Boronins, St. Petersburg visitors who regularly bought his vegetables. In exchange, the Väisänens could use the Boronins' land however they wished. This allowed Aino's large family to move to this spacious property. After losing all contact with the Boronins, the Väisänens sold the premises in 1926 (Knuutila 1984).

This article addresses how state-building practices distinguishing between insiders' and outsiders' access to rights and privileges reflected the significance of territorial borders as markers of a state's territorial sovereignty. It does so by investigating how Finnish-Russian social ties affected the Finnish government's management of real estate owned or used by subjects of the former Russian Empire. It examines how property settlement decisions had unintended consequences when officials attempted to balance state and individual interests. This study is part of a broader project on various ways that Finnish-Russian social contacts in the border regions impinged on state-building, as well as the way state efforts to exert control over these areas affected daily micro-level interactions. The primary sources selected for this study represent a subset of materials pertaining to property claims.

Borderland theorists have commented that the post-Westphalian nation-state often imposed political boundaries on the population with little regard to its social structure (Zartman 2010, 3). The post-1917 Finnish-Soviet border, accompanied by the tenuous relationship between these two new states, had real life consequences for people with actual and imagined connections across this boundary because it was tied to nation- and state-building processes. Many Russians who possessed immovable assets in Finland resided seasonally in the Karelian Isthmus. Yet government authorities' attempt to transfer Russian-owned properties to the Finnish state unearthed long-term effects that decades of Finnish-Russian interaction

* $\quad$ PhD Candidate in History at Michigan State University, 256 Old Horticulture, 506 E. Circle Drive, East Lansing, MI, 48824, USA | lamkitt1@msu.edu 
had on the region. This case reminds us that borders are not merely spatial distinctions but are also social sites that cut through lives, cultures, economies, and identities (Halle 2007, 77). Border scholars have long argued that "the boundary does not limit itself merely to the border area or landscape itself, but more generally manifests itself in social and cultural practices and legislation" (Newman and Paasi 1998, 196). Socio-cultural practices related to citizenship and belonging can complicate a border's role as a political structure, even if such practices are not directly tied to a boundary's physical presence. It is therefore important to consider how micro-level social transactions can have broader effects on the meaning of borders as markers of territorial political sovereignty.

Stephen Lovell's (2003) Summerfolk skillfully illustrates the rich history of the dacha, the Russian summer home, as a distinctive social and cultural institution in late Imperial Russian society. His work illuminates how $19^{\text {th }}$ century urban conditions made these secondary summer residences popular among Russian families of varying income. Natalia Baschmakoff and Mari Ristolainen (2009) emphasize Russian artists', musicians' and writers' contribution to the Karelian Isthmus towns, and the inspiration that the Finnish landscape offered these intellectuals. Vilho Hämäläinen $(1974,1983)$ underscores the political and strategic aspects of the Finnish Senate's decision to allow Russians to acquire properties along the Gulf of Finland. These works provide a rich context for examining the how the Finnish state took over these border area properties as part of its state-building project.

\section{Historical and Theoretical Context}

The Karelian Isthmus had been under both Swedish/Finnish and Russian rule over several centuries, thus creating a complex setting for Finnish-Russian contact. Although the intensity of these activities waxed and waned with wars between Sweden and Russia, they persisted in spite of geopolitical changes (Katajala 2007, 75-77). They were possible because no formal bureaucratic institution scrutinized migration between these lands. From 1809 to 1917, the Grand Duchy was an autonomous part of the Russian Empire, delineated from the rest of the empire by a customs border. In 1812, the Finnish Customs Department established checkpoints to monitor goods traffic between Finland and Russia, but these were merely "local manifestations of the increasing control over space rather than expressions of boundaries dividing the space" (Paasi 1996, 167). Again, the border had little practical implication for those whose lives frequently traversed it; border control was not institutionalized in most parts of the world until the $20^{\text {th }}$ century. Russian subjects who belonged to mobile estates could travel to Finland with relative ease. Likewise, numerous Finnish farmers and workers who lived in eastern Finland traveled to St. Petersburg and nearby villages (Engman 1977, 161). The lack of a formal political boundary with strict controls on human mobility meant that this region hosted residents of various social and cultural backgrounds. Stephen Lovell has proposed that the Russian summer house settlements may be considered "a by-product of urbanization thus analogous to forms of settlement elsewhere in the developed world" (2003, 1). Many of the St. Petersburgers who vacationed in the Karelian Isthmus villages saw the area as a suburban extension of the imperial metropolis. A popular guide on summer settlements referred to those villages as places slightly further along the railroad from St. Petersburg (Fedotov 1899, 3). People who lived near the FinnishRussian border carried on with their lives with little regard for what the border symbolized politically.

The Finnish-Russian border zone at the beginning of the $20^{\text {th }}$ century, like many others in different times and places, was a complex spatial setting charged with paradoxes and contradictions. In the Russian context, borderlands equal peripheries, but the Finnish-Russian border zone was also imagined as an extension of the imperial capital in St. Petersburg, both foreign and familiar to Russians. Daphne Berdahl has argued that border zones "are often fields of heightened consciousness that demand articulation or identification" (1999, 7). They are also "intersecting, overlapping, and often, mutually constitutive cultural fields" and as such they "may also have real spatial dimensions and implications" (Berdahl 1999, 7). Throughout the $19^{\text {th }}$ century, Finns and Russians had regular contacts with each other in the Karelian Isthmus. Interactions in this borderland were neither completely peaceful nor constantly wrought with tension, but they contributed to nested socio-economic networks that brought together people from 
different cultural and occupational settings. Tara Zahra $(2008,8)$ has commented that in focusing on competing nationalisms, scholars risk characterizing borderlands either as places of violent interethnic conflict or as sites of idyllic cooperation. It is therefore important to examine social interactions in borderlands on a spectrum from amity to conflict.

The networks that bound the Karelian Isthmus' Finnish residents and Russian visitors functioned within a backdrop of rising political tension. Finnish nationalist activists became increasingly concerned with what they assumed to be Russian authorities' fortified attempts at Russification. Officials in Russia worried that what they perceived to be the Finnish people's strengthening aspiration for sovereignty would undermine the empire's security. These tensions affected the Karelian Isthmus directly in 1907 when the Council of Ministers considered turning over the three parish districts with the highest concentration of Russian summer house owners to St. Petersburg's administration. According to Vilho Hämäläinen, this decision was made under the pretext of protecting Russian subjects' interests in the region, but with the intent of securing a military zone in the St. Petersburg environs (Hämäläinen 1974, 173). These discussions affected daily interactions between Finnish villagers and Russian visitors in the Karelian Isthmus: in 1908, taxi drivers from one town went on strike as an expression of their dismay at talks of new administrative arrangements (Baschmakoff and Leinonen 2001, 30). These tensions affected the nature of cross-cultural contacts.

It is possible to argue that the post-1917 border changes stranded people on the "wrong" side of the boundary, since they cut off many Finns living on the Russian side and left some Russians stranded in Finland. Anssi Paasi offers a more nuanced description of the situation. He posits that the boundary was functionally located in the "wrong place," since it immobilized people whose social and economic activities spanned both sides of the new divide $(1996,169)$. The establishment of a new border regime disrupted social transactions between local villagers and seasonal visitors. Michiel Baud and Willem van Schendel have argued that national borders are "imagined projections of territorial power" (1997, 211). In the years immediately after Finland's declaration of independence, state authorities prioritized securing the border region for military reasons. Their plans included expelling Russian military personnel and heavily restricting the number of people who could reach Finland from Russia. These efforts can be seen as authorities' attempts to turn the state's imagined territorial power into reality. However, individuals acted within their daily social realms to mitigate the effects of these restrictions. These actions called into question the border's role in delineating a state's control over territory. In doing so, borderland people's activities also challenged the political meaning of borders.

The Finnish authorities' attempts to control border areas were set in a wider political context of uncertainty over how regime change in Russia could affect Finland's sovereignty. These efforts were pertinent, given the territorial disputes between Finland and Bolshevik-controlled Russia from 1918 to 1921 (Engman 2007). The anti-Russian rhetoric espoused by Finnish nationalists in reaction to Russification at the end of the $19^{\text {th }}$ century did not dissipate once the imperial system disintegrated. Instead, anti-Russian sentiments were fused with anti-Bolshevik expressions. Paasi has commented that although the Finnish population did not originally espouse extreme right-wing groups, ideas proposed by the academic intelligentsia became crucial for developing territorial ideologies based on anti-Russian patriotism $(1996,99)$. During the first decade of Finland's independence these ideologies became the dominant view in Finnish public life. The populist association, the Academic Karelia Society, gained notoriety for its campaign to homogenize the border regions for ethnic Finns (Karemaa 1998, 19).

Paasi contends, "nationalism is a specific form of territoriality" that "looks inward in order to unify the nation and its constituent territory" and is "always concerned with a struggle over the control of land" (1996, 51). Subjects of the defunct Russian empire owning landed property in a Finnish region adjacent to the Russian border potentially threatened the new state's territorial integrity. Eric Hobsbawm (1983, 9) theorized that nationalism involved elites' invention of traditions, rituals and symbols that imply continuity with the past to establish boundaries of social cohesion and membership. In this constructed national 
narrative, Finnish right-wing groups imagined Russians as their hereditary enemy (Paasi 1996, 159). Issues of border and territorial control were thus fused with ideas about nationalism. This implied continuity, however, did not necessarily correspond with social reality. Evidence of Russian home ownership in the Karelian Isthmus and the activities connecting Russian homeowners to their Finnish neighbors brought into question the extent to which Finns and Russians regarded each other as enemies. It also challenged the idea that the region "naturally" belonged to the Finns. Diverse interactions in this border region meant that state actors' efforts to exert control over this territory could not simultaneously satisfy a nation-building and a state-building agenda. Finns' and Russians' efforts to challenge the Finnish state's efforts to control property underscored the border's ambiguity as a marker of state sovereignty over space and place.

Hastings Donnan and Thomas M. Wilson $(2010,2)$ have commented that borders have been seen as structures of state and national security that disrupt the politics of the nation if penetrated. This notion is heightened during wartime, especially where boundaries had previously not been attached with such security meanings, as was the case between Finland and Russia. With the onset of the First World War, the number of summer visitors from Russia to the Karelian Isthmus began to dwindle. Anxious about vulnerability to German attack, many Russians stopped visiting, and some who resided there permanently retreated inland (Balashov 1996, 34-35). By the end of 1917, those who had originally returned to Russia during the war now sought refuge from the Bolsheviks in their Karelian Isthmus homes, along with those who had remained in the region through the war (Nevalainen 2003, 17). The post-1917 Finnish-Russian border followed the contours of the Grand Duchy's customs boundaries, but its role completely changed when state authorities established patrols and special border guard detachments in the border regions (Paasi 1996, 169). Because of changes to border controls, many Russians were unable to care for their properties located in Finnish territory. Those in Russia could not personally tend to their summer homes, while those in Finland could not mobilize resources to do so. Most owners were unable to pay taxes once political turmoil eased in the mid-1920s. The state annexed much of the abandoned properties once the Russians disappeared en masse (Lähteenmäki 2009, 299). The new border between Finland and Russia had barely been etched out, but the Finnish state was already taking measures to solidify control over territory and property on its side of the boundary.

In some cases, the government even sequestered houses with living inhabitants. One memoirist recalled that in one village, a St. Petersburg hat maker bequeathed land from his large villa to the Finnish Lutheran Church in St. Petersburg as a shelter for impoverished widows. The council that ran the St. Petersburg Finnish Lutheran congregation also directed this shelter. When civil war hostilities in Finland ended in May 1918, the shelter remained on the Finnish side of the border, and the administration was stranded on the Russian side. Since no one could pay the property taxes, the Finnish state took custody of the property. Land settlement authorities displaced the women living in the home and leased the premises to other parties (Pukonen 1959). The authorities' efforts to assert administrative control over the border region severed the bonds between the donor and the destitute Finnish women he had intended to assist, and in doing so, deprived these Finns of their security.

Those Russians who remained in Finland after the Finnish civil war ended in the spring of 1918 found themselves in an equally difficult situation. Government policies aimed to limit the number of Russians in Finland. This involved denying citizenship applications to Russians and complicating their business activities (Lähteenmäki 2009, 299). Living in a state where they could not maintain their livelihood, they had limited means for paying taxes. Some managed to retain their properties and subsisted by putting up boarders or planting vegetables on their plots (Baschmakoff and Leinonen 2001, 53). Others attempted to sell their real estate as a last resort.

\section{Bargain or Burden?}

Control over borders can be seen as part of a state's strategy for managing distribution of resources to those who rightfully belonged to the polity. This is a significant aspect of governance for modern states 
concerned with territorial forms of citizenship. It is easy to surmise that the Finnish government associated control over a precariously defined border region with control over private property. Before considering whether Finnish policies on foreign-owned land can be construed as part of a nativist policy directed against Russians in a region with strong ties to Russia, it is vital to consider this issue from a pragmatic perspective. Finnish authorities could not ignore the problem that thousands of people had abandoned their properties and owed an enormous amount in property taxes. Since the state also struggled with land and housing shortages, annexing the real estate appeared to be the most direct solution. The Board of Settlement oversaw the distribution of estate lands to improve the plight of the landless (Pihkala 1952, 148). Sorting out the legal aspects of the large number of Russian-owned real estate required a much more concentrated effort. On October 20, 1922, the government created the Administrative Organ as a special section of the Board of Settlement to handle foreign-owned properties (Karjala, November 2, 1922).

The Administrative Organ attempted to ensure that property on Finnish soil, demarcated by a precariously defined boundary separating it from a state that might lay potential claims to its territory, remained in Finnish hands. However, vaguely worded legislation regarding foreigners' land ownership rights complicated these tasks. A 1920 Finnish law stipulated that foreigners who did not reside in the province in which they held property titles did not have the right to control property in Finland without special permission. But as members of the Administrative Organ noted in a letter to a cabinet minister, "control of property" and "special permission" were not clearly defined (Administrative Organ 1923a). Nonetheless, since many Russian summer house owners had already fled the area, the state seized their properties in accordance with the 1922 Law on Property in Finland Abandoned by Foreign Owners. If no owner came forward to claim the property after 5 years had lapsed, the state would be entitled to appropriate it. Since Article 7 of this law in theory permitted Russian owners to redeem their real estate within 5 years of its seizure, the 1922 law inherently contradicted the 1920 legislation that prohibited foreigners from owning property in Finland without special authorization (Finnish Acts and Decrees 1922). The right to redemption was thus subject to authorities' discretion based on criteria external to legal provisions.

State-building in the border region was more nuanced than a clichéd struggle to homogenize ethnically diverse areas and make state boundaries congruent with ethnicity. The Administrative Organ's interpretation of property ownership laws and real estate sales indicated that its priority was ensuring that the Finnish State had the financial advantage. Preventing Russians from amassing significant assets was a notable by-product. In the wider context of property rights, the state regulation of property ownership for monetary purposes is not unique. Scholars studying property rights have long recognized the relationship between government and property, and that the state generally specifies rules to serve its own fiscal interests in tax revenues (Ariovich and Carruthers 2004, 29). The numerous villas that wealthy Russian summer guests owned provided a source of income for the Finnish state. The government used some of the assets from these properties to finance border patrols (Lähteenmäki 2009, 301). Property issues were linked in a concrete way to maintaining the border's integrity.

Ironically, the border as an institution marking national territory accentuated practical dilemmas in the state building process. The worsening condition of abandoned summer homes troubled authorities who prioritized state fiscal gains. At a board meeting in April 1923, representatives from parish districts with large numbers of abandoned properties discussed financial consequences. The chairman desired that the abandoned properties "be taken into the state's care as soon as possible, since these properties have now been abandoned for about five years." He acknowledged that it could be less costly for the state to allow Russians to redeem and sell these plots because the government would not have to pay for repairs. The state could recoup unpaid tax revenue through property redemption fees and shift the burden of restoration to the original owners (Administrative Organ 1923b). Subsequent rulings suggested that economic expediency gave state agents incentive to permit some Russian and Soviet citizens to reclaim less valuable lands. For example, Ivan Ivanoff was able to reclaim his property after the Administrative Organ turned it over to the state in April 1923. The Viipuri Provincial Governor approved the return of this property on condition that Ivanoff paid 25 Finnish Marks per month to the state appointed caretaker who 
looked after the property when it had been in state custody (Viipuri Province Governor's Office 1923). These practical concerns underscored the cost of using territorial borders as a dividing line between economically and culturally linked peoples and places.

These decisions acknowledged the Russians' economic significance to the Karelian Isthmus as well as the barriers that a new border regime posed for them. Whether this entailed goodwill on behalf of the Administrative Organ officials toward Russian property owners remains debatable. Since ambiguity in border controls still made it difficult for Russians to travel to Finland, redemption was only open to those already residing in Finland, or to those in Russia able to negotiate property claims through a Finnish acquaintance. The applicant was required to pay outstanding property taxes and pay for the property's maintenance while it was in state possession. The value of the applicant's real estate was usually not high enough to compensate for the start-up costs associated with re-acquiring it. Raising such sums was mostly beyond the financial means of those without gainful employment in Finland and those who lacked the social networks to assist with this purpose.

Economic factors affected state efforts to control border areas, with ancillary consequences for FinnishRussian interactions. Russians' material well-being and their entitlement to property ownership were addressed only if they did not interfere with government priorities. That the debate on what should be done with real estate in good condition for which ownership was in question underscored this factor. The consensus was that the state should immediately expropriate and auction off these properties before another party claimed them. The chairman claimed this practice was prompted by the prevalence of cases where soon after the Administrative Organ had announced its intention to appropriate valuable property, "an agent who had bought the said real estate or had a letter of attorney permitting him to sell it always appeared." The Administrative Organ would thus be required to postpone seizure and sale of this property until an investigation could determine whether the said agent's claims were legitimate (Viipuri Province Governor's Office 1923).

The Administrative Organ's preoccupation with maintaining the state's financial advantage in dealing with property ownership sometimes inadvertently penalized Finnish citizens who purchased property from Russians, especially when the ownership chain could not be clearly established. Kalle Kakko had purchased land from one Russian merchant in 1924, a small part of which had been parceled out and sold to another Russian in 1917. Since only one part of the plot was neglected, the Finnish state should only have been entitled to expropriate that small section. Nonetheless, upon examining the original sale agreement between the Russians, the Administrative Organ turned the entire property over to state control on the grounds that the contract did not clearly specify the property's delineation, and therefore the entire property could be considered abandoned (Viipuri Province Court of Appeals 1926).

In another village, the Sirki family faced similar obstacles in their May 1924 purchase of dacha property from two Russians. The Vojeikoff brothers had inherited this property from their father in 1916, but the Administrative Organ argued that because the brothers had not provided sufficient proof that they were the legal heirs, they had no right to ownership. The Supreme Court of Finland (1923) voided the sale between the Voijeikoffs and the Sirkis, and allowed the state to sequester this real estate, thus depriving the Sirkis of valuable farmland. Josefina Toivonen's case paralleled the one mentioned above. She had purchased property from Leningrad acquaintances who inherited the real estate from their father in 1918. The Administrative Organ had deemed this sale illegal, claiming that since the landlord had died in Russia in 1918, his sons' inheritance rights could not be verified. By preventing real estate transactions between a Finn and a Russian, the Administrative Organ sacrificed the Finnish citizen's interest in favor of state financial gains. The state's efforts to assert control over property in the border areas ended up marginalizing borderland inhabitants. In doing so, the state subordinated nation building interests to state building ones.

Protecting state fiscal interests through repossession of abandoned properties was much more complicated than authorities had envisioned, and it eroded the meaning of the Finnish-Russian border as a marker 
denoting territories that belonged to Finland. The complex task of transferring Russian-owned properties to Finnish hands raised several larger issues that legislators had not anticipated. By allowing Russians to repossess less valuable properties out of financial expedience, would Finnish officials subsequently be required to recognize Russian property owners' legal rights in Finland? Would this solution lead to public recognition of these Russians' previous connections and contributions to the Karelian Isthmus dacha towns, thereby legitimizing their right to permanent residence in Finland when there was increasing pressure to limit their presence in Finland? In ensuring the Finnish state's gain from transferring property out of Russian hands, the Administrative Organ also disadvantaged Finnish citizens who had direct contact with the Russian proprietors. What unforeseen implications would this have for future policies?

\section{Trustworthy Trustees?}

Borders matter when tied to specific state-building practices designed to distinguish between those who belonged to the polity and those who did not. However, borders and efforts to control movement across them cannot undo the legacy and memory of past social-economic contacts within a region bisected by a new border regime. Paradoxically, this factor puts into question the notion of borders as gatekeepers. The tenuous relationship between boundary maintenance and state-building practices is heightened when individuals' access to resources come into play.

The Finnish-Russian border did not sever all bonds between Finnish villagers and Russian proprietors. This factor made it difficult for Finnish authorities to transfer property solely to Finnish hands. State-building priorities were therefore not entirely compatible with nation-building ones. Some Russian landlords who were able to re-establish contacts with acquaintances in Finland opted to assign their Finnish associates as temporary caretakers in efforts to keep their assets. Russian citizen Maria Schukovnova (1923) entrusted two dachas to a neighboring farmer for maintenance. A Russian colonel's wife turned over her property, which had been in her family's possession since 1891, to a police officer for temporary care (Golubzova 1925). Finns who took over temporary care of land for absentee owners dealt with rentals, maintained buildings, and most importantly, paid property taxes (Mushketova 1925). Other Russians with no plans to return to Finland entrusted their properties to Finnish citizens for temporary care in hopes of recouping sales revenue. One Russian couple drew up a letter of attorney that allowed a Finnish citizen to sell their property in the Terijoki village "in order to raise funds for themselves," although this document did not specify how proceeds from the sale of this property was to be transferred (Ausin and Ausin 1925).

Members of the Administrative Organ were well aware of this practice, and worried that this legal loophole allowed the absentee Russians to remain de facto property owners. The Administrative Organ's letter to Minister Niukkanen stressed that the 1920 law requiring foreigners to have special permission to own property in Finland did not prevent a foreign proprietor from appointing another person to manage his real estate in Finland. "When the foreign citizen issues a letter of attorney that gives the recipient rights of guardianship, this would in effect permit the foreigner to control his property in the Viipuri province, thus breaking the spirit of the 1920 law" (Administrative Organ 1923a). In reality, appointing a trustee to sell their properties did not necessarily mean a significant financial advantage for the Russian owner abroad. One person recalled how he had arranged the sale of an acquaintance's home. The notary in charge informed him that there was little interest in the area where the house was located, since many of the other properties in the area were abandoned, thus detracting from the value of properties in the area (Baschmakoff and Leinonen 2001, 54-55).

Judicial authorities nonetheless permitted these arrangements when a Finnish citizen was appointed as the trustee. The Administrative Organ had turned over an apparently abandoned farm, owned by a Russian subject, to the Finnish state. When a Finnish citizen submitted a letter of attorney to the Administrative Organ demonstrating that the owner had given him legal rights to the farm, the highest court in the Viipuri Province approved the transfer of this real estate after having confirmed the deal's legality (Administrative Organ 1924a). Article 10 of the 1924 amendments to the 1922 legislation eventually 
established a clearer guideline on redemption of property by a legal trustee appointed by the original owner. It gave the trustee 5 years time from the original date of the property's seizure to redeem it on the owner's behalf (Finnish Acts and Decrees 1924).

These arrangements prolonged permanent property transfer to the Finnish state, diverted revenue to foreigners, and had few benefits for the Finnish trustees besides direct access to the buildings and land on the property, but they solved some immediate practical problems. The Finnish trustees would be responsible for property maintenance, thus preventing the real estate from further deterioration and devaluation. The Finnish trustees would also be responsible for paying outstanding taxes, ensuring that the state would still collect revenue from these properties. In cases where the state had already seized a Russian-owned property, the Finnish citizen who possessed a letter of attorney permitting him to control the real estate was responsible for paying the state-appointed caretaker who had tended to the property. This provision relieved the state's obligation to pay individuals for the upkeep of unoccupied premises. One Finnish shopkeeper who petitioned the Viipuri Province Governor for control of a Russian nobleman's estate was allowed to do so on the grounds that he paid a modest salary to the state-appointed caretaker who had been looking after the estate (Stenius 1924). These types of transactions underscored the complexity of officials' efforts to balance state priorities and individual entitlements in ways that could satisfy both state-building and nation-building interests.

These relationships and their associated legal transactions also raise the issue of trust and dependency between the Finns and Russians engaged in these contracts. Since the new border regime complicated communications between Russians and Finns, it became imperative for the owner to have a trustworthy trustee. A Russian who appointed a Finnish citizen as his legal trustee required reasonable assurance that the Finnish citizen would fulfill the tasks required of him or her, and more importantly, ensure that the original proprietor would receive the revenue generated by property sale or rental. This accentuates a reversal of roles that took place when Finland became an independent state. A number of the Russian villa owners had previously been the wealthier members of their small communities. Farmhands, nursemaids, and shopkeepers in these parish towns even depended on wealthier Russians for jobs. When Russian landlords began to face obstacles in maintaining property rights, their livelihoods now depended on the farmers and shopkeepers whom they had appointed as their legal trustees.

From the available documents, it is difficult to discern the exact nature of the previously existing relationship between the Russian owners and the Finnish caretakers. But since these village communities were small, these people kept intermittent contacts with each other. The informal customs boundary between Finland and Russia prior to 1917 facilitated regular interactions between Finns and Russians. Aino Väisänen's testimony suggested that Russians sometimes entrusted those Finns who served them-farmers and shopkeepers, for example - with the care of their properties. These people crossed legal paths even years after the imperial relationship between Russia and Finland was severed. It could be argued that by asserting their legal right as trustees for Russian proprietors, Finnish citizens were taking advantage of new opportunities to gain access to lands that for decades had been held by affluent St. Petersburgers. Yet these legal transactions also point to the human mobility between Finland and the Russian Empire that enabled these operations. Moreover, these encounters connected people of different socio-economic and occupational backgrounds. Though the relationship between the summer house owners and temporary property caretakers may not have been intimate, establishing this contractual relationship would not have been possible if the Russian visitors had not established prior social networks that included Finns. Efforts to institutionalize the FinnishRussian boundary could not curtail the significance of these relationships. Government officials faced difficulties determining how to satisfy state financial interests while honoring Finnish citizens' entitlements.

\section{Debtors and Creditors}

In many instances, institutionalized border controls do not clarify state authorities' tasks in allocating resources to rightful residents of the state. Finnish citizen Gunilla Virki rented out a section of her 
property to a Russian subject for use as a summer home. Virki claimed that after some time, her tenant disappeared, owing her unpaid rent dating from June 1915 to June 1925. Her request for rent compensation from the Administrative Organ was denied on the grounds that it was unreasonable (Administrative Organ 1926a). Economic interdependency between local Finns and Russian visitors also affected daily life in Karelian Isthmus towns after Finland's independence through a debtor-creditor relationship. Many Russians rented property from local Finnish farmers, and this proved ominous for some Finns when border regime changes displaced their Russian tenants. The Russians' rental payments had been a steady source of the Finnish farmers' property tax contributions. When many of the tenants disappeared, Finnish farmers who had rented parts of their farmsteads to Russian families could not pay their taxes. Consequently, these Finns' properties were also under threat of expropriation while the owners' debts accrued. The Finnish government could not easily compensate its citizens without fiscal consequences for the state.

The Administrative Organ faced the complex task of determining whether landowners were truly paralyzed by their Russian tenants' inability to pay rent or if landlords were using absent rent payment as a pretext for evading taxes (Administrative Organ 1926b). In order to assess Finnish landholders' claims, government authorities inevitably investigated details of the relationship between Finnish landlords and their absentee Russian tenants. Regardless of state representatives' attitudes towards these relationships, agreeing to ease Finnish subjects' tax burden due to Russian tenants' debt could set off an unpleasant precedent whereby the Finnish state would then be taking on responsibility for these Russians' inability to pay rent. This would require government officials to sacrifice state fiscal priorities for the sake of individual Finnish citizens' interests.

Other types of creditor-debtor relationships also affected the Administrative Organ's activities. One case concerned Finnish attorney Herman Beyrath's claim that Russian actress Anna Datschkova owed him a significant amount of money. Beyrath argued that he should receive the assets of Datschkova's real estate as compensation, but the property was already in state custody. Although local parish courts ruled in his favor, the Administrative Organ implored the Viipuri Province Court of Appeals to overturn this decision (Administrative Organ 1924b). The Administrative Organ then turned to the Supreme Court of Finland for a final ruling. The petition mentioned that if a property owner had borrowed from a creditor, the debtor had the right to mortgage the property to pay the debt. This situation became complicated when after a state had annexed the real estate, a creditor claimed the revenue the state received from the property due to the previous owner's debt to him. The question became whether the state should be liable for paying the debts of an individual whose property the state had already confiscated (Administrative Organ 1924c).

In the early years of the Administrative Organ's existence, authorities were already concerned about consequences for the state if a creditor was permitted to seize properties already in state possession as compensation for debts. The Administrative Organ worried that should this be the case, the state would not be able to recuperate expenses incurred for property maintenance, and thus the state would have the most to lose when annexing abandoned real estate (Administrative Organ 1923a). The Administrative Organ made a small compromise in its petition. While insisting that the state should continue to receive revenue from properties seized, it also acknowledged that it was unfair for creditors to be denied compensation from debtors whose property the state had already confiscated. It suggested that the Supreme Court amend the Viipuri County Court of Appeal's decision so that the right of redemption for that property should be transferred to the creditor. He may then dispense with the property as he wished, and the state would not be directly responsible for repaying this debt (Administrative Organ 1924c).

This case suggests that land authority representatives, legislators, and judicial authorities did not always agree on the interpretation of laws pertaining to Russian-owned property, especially if they affected the balance of public versus private interests. On the one hand, compensating the Finnish creditor potentially implied acknowledging that whenever the state seized Russian-owned property, it may also be required to 
carry the Russian's financial burdens. On the other hand, the courts could rule in favor of the Finnish state, and reject the creditor's compensation claims, but this option would disadvantage the Finnish citizen. In the Beyrath case the courts and land settlement agents struggled to find common ground due to the wide range of implications the final decision on this case could have. These discussions underscore the intricacy of interethnic relationships that affected a state's efforts to assert control over a borderland area.

The debtor-creditor relationship between former Russian subjects and Finnish citizens reveal further layers of complexity in Finnish-Russian contacts that may not have been initially obvious. Late $19^{\text {th }}$ century Russian society often associated the dacha with the urban middle class. This group consisted of people who, in Lovell's words, "did not do physical labor or perform menial service yet were not grandees or landowning nobles." The income boundaries of this group were amorphous and included a diverse range of people "from mandarins all the way to shopkeepers" $(2003,4)$. By the early $20^{\text {th }}$ century, less affluent Russians increasingly borrowed money from the growing Finnish middle class. Finnish small farmers, too, profited from the Russians' yearning for exurban pleasures. Renting out their farmhouses to St. Petersburgers enabled Finnish farmers to earn supplementary income (Hämäläinen 1984, 118). These transactions brought Finns and Russians of different economic circumstances into dialogue with each other, and Finnish authorities confronted this in the early 1920s when balancing state priorities with Finnish citizens' financial well-being. The enduring effects of these Finnish-Russian contacts made it difficult to determine exactly what "Finnish" objectives were. Safeguarding Finnish interests was more complicated than imposing strict measures on Russians.

\section{Conclusion}

This article has attempted to illustrate the relationship between territorial boundaries, state prerogative in managing resources, and everyday relationships at a local and regional level. In the $20^{\text {th }}$ century, especially within recent decades, lawmakers have justified tightening border controls by claiming the need to prevent outsiders from accessing state resources such as healthcare and education. Such controls, however, cannot be separated from practical concerns that might contradict the border's role as a gatekeeper. The examples in this study remind us that the connection between territorial boundaries and control of state resources can be an ambiguous one, especially when individuals' social interactions are taken into consideration.

Nationalism is intrinsically related to territory in the sense that nationalizing states often attempt to make territory congruent with nationality. Borders are an important aspect of this equation because they can be regarded as structures that denote the spatial extent of state sovereignty. Border scholars have addressed people's attempts to traverse territorial boundaries in spite of government attempts to limit these movements. These limits do not just refer to mobility across guarded boundaries. Borderland peoples can complicate national interests without physically crossing a territorial border. They do so by evoking relationships where people's daily activities might bring them into contact with those from the other side of the divide. State actors, however, are not always successful in untangling these cross-boundary connections without subordinating nation-building interests to state-building ones or vice versa. Authorities' attempts to impose administrative order in border regions resonate with larger themes on relations between state actors and individual citizens. Issues presented in this article are therefore relevant for border scholars because it shows how practical concerns such as access to certain rights, privileges and resources can challenge the primacy of the border as gatekeeper between insiders and outsiders.

The cases presented in this study indicate that protecting the Finnish state's financial interest was the primary factor motivating officials' handling of Russian-owned property in the first decade of the country's independence. It is tempting to assume that officials explicitly sought to deprive Russians of their assets in Finland pursuant of a nativist agenda because anti-Russian movements continued to gain momentum in the 1920s. Permitting Russians to own a vast amount of property in a region that Finnish nationalists considered a battleground for competing influence with Russia seemed counter-productive to the statebuilding program. However, this view is misleading because it overshadows significant practical dilemmas 
that complicated governance in a border region. Officials made decisions on property claims within a backdrop of uncertainty over whether Russian proprietors would be free to traverse the Finnish-Russian border as they had done for decades prior to Finland's secession from Russia. The immediate fiscal imbalances resulting from mass abandonment of valuable property also affected authorities' judgment.

Defending national interests by transferring Russian owned real estate to the Finnish state was in reality a much more convoluted affair. Finnish authorities' concern with Russian-owned property related to their efforts to assert control over border regions that were sites of Finnish-Russian interaction. In the process of managing territory and property, officials inadvertently marginalized borderland inhabitants. Although land settlement authorities had been charged with the task of resolving land and housing shortage problems by confiscating abandoned property, expropriation practices did not benefit Finnish citizens uniformly. Varying degrees of economic interdependency between the Russian summer inhabitants and the local Finns they encountered in the Karelian Isthmus made it at times difficult to expropriate Russian properties without negative consequences for certain Finnish citizens. When there were conflicts of interest between state revenue and individual gains, legal decisions sometimes privileged the state at the citizen's expense. In many of these cases, Finns who actually had intimate and regular contacts with the Russian seasonal residents gained very little from the state's efforts to transfer property from Russians to the Finnish state. Although the annual exodus of Russian summer visitors to the Karelian Isthmus was physically a part of the local landscape for a short time, the effects their contacts with local Finns who resided there permanently had a much longer afterlife.

\section{Endnote}

${ }^{1}$ Transliteration of Russian names follows the Library of Congress system if the original source is in Russian. Russian names appearing in Finnish sources will be transliterated according to Finnish standards.

\section{References}

Administrative Organ for Property of Foreign Owners in Viipuri Province. 1923a. Letter to the Board of Settlement, October 24. Mikkeli Provincial Archives in Finland. Administrative Organ Archive Series Da4.

Administrative Organ for Property of Foreign Owners in Viipuri Province. 1923b. Board meeting report, April 15. Mikkeli Provincial Archives in Finland. Administrative Organ Archive Series Cb1.

Administrative Organ for Property of Foreign Owners in Viipuri Province. 1924a. Decision on Ukkonen petition, October 27. Mikkeli Provincial Archives in Finland. Administrative Organ Archive Series Eb3.

Administrative Organ for Property of Foreign Owners in Viipuri Province. 1924b. Petition to the Viipuri Supreme Court, April 15. Mikkeli Provincial Archives in Finland. Administrative Organ Archive Series Da4.

Administrative Organ for Property of Foreign Owners in Viipuri Province. 1924c. Petition to the Supreme Court of Finland, November 24. Mikkeli Provincial Archives in Finland. Administrative Organ Archive Series Da4.

Administrative Organ for Property of Foreign Owners in Viipuri Province. 1926a. Board meeting report, August 9. Mikkeli Provincial Archives in Finland. Administrative Organ Archive Series Cb1.

Administrative Organ for Property of Foreign Owners in Viipuri Province. 1926b. Memo to the Board of Settlement, January 30. Mikkeli Provincial Archives in Finland. Administrative Organ Archive Series Da4.

Ariovich, Laura, and Bruce Carruthers. 2004. The sociology of property rights. Annual Review of Sociology 30: $23-46$. 
Ausin, Alisa Lovisa, and Andrei Ausin. 1925. Letter of attorney, June 4. Leningrad Oblast State Archive in Vyborg, Russia, F.505, op.1, d.6, 1.3.

Balashov, Evgenii. 1996. Karel'skii peresheek: zemliia neizvedannaia. St. Petersburg: Geza Kom.

Baschmakoff, Natalia, and Marja Leinonen. 2001. Russian life in Finland: A local and oral history. Helsinki: Suomen Historiallinen Seura.

Baschmakoff, Natalia, and Mari Ristolainen, eds. 2009. Dacha Kingdom: Summer dwellers and dwellings in the Baltic Area. Helsinki: Aleksanteri Institute.

Baud, Michiel, and Willem van Schendel. 1997. Toward a comparative history of borderlands. Journal of World History 8 (1): 211-42.

Berdahl, Daphne. 1999. Where the world ended: Re-unification and identity in the German borderland. Berkeley: University of California Press.

Donnan, Hastings, and Thomas M. Wilson, eds. 2010. Borderlands: Ethnographic approaches to security, power, and identity. Lanham, MD: University Press of America.

Engman, Max. 1977. Migration from Finland to Russia during the nineteenth century. Scandinavian Journal of History 3 (2): 155-77.

Engman, Max. 2007. Raja: Karjalankannas 1918-1920. Helsinki: WSOY.

Fedotov, N. 1899. Illiustrirovannyi putevoditel' po dachnym, vodolechebnym i zhivopisnym mestnostiam Finliandii. St. Petersburg.

Finnish Acts and Decrees. 1922. Law on Property in Finland Abandoned by Foreign Owners.

Finnish Acts and Decrees. 1924. Law on Property in Finland Abandoned by Foreign Owners Amendment.

Halle, Randall. 2007. Views from the German-Polish border: The exploration of inter-national space in "HalbeTreppe" and "Lichter". German Quarterly 80 (1): 77-96.

Hämäläinen, Vilho. 1974. Karjalan kannaksen venäläinen kesäasutus ja sen vaikutus Suomen ja Venäjän subteiden kehitykseen autonomian ajan lopulla. Tampere: Tampereen yliopisto.

Hämäläinen, Vilho. 1983. Karjalan kannaksen venäläinen kesäasutuskysymys maamme itsenäisyyden kaudella. Tampere: Tampereen yliopisto.

Hobsbawm, Eric. 1983. Introduction: Inventing traditions. In The invention of tradition, eds Eric Hobsbawm and Terence Ranger, 1-14. Cambridge: Cambridge University Press.

Karemaa, Outi. 1998. Vihollisia, vainoojia, syöpäläisiä. Rasistinen venäläisviha Suomessa 1917-192. Helsinki: Suomen Historiallinen Seura.

Katajala, Kimmo. 2007. Cross-border trade in Karelia from the Middle Ages to the October Revolution 1917. In The flexible frontier: Change and continuity in Finnish-Russian relations, eds. Maria Lähteenmäki, 70-87. Helsinki: Aleksanteri Institute.

Knuutila, Aino. 1984. Karelian life history manuscript. Folklore archives of the Finnish Literature Society. Series KE 35: 7359-76. 
Lähteenmäki, Maria. 2009. Maailmojen rajalla: Kannaksen rajamaa ja poliittiset murtumat 1911-1944. Helsinki: SKS.

Stephen Lovell. 2003. Summerfolk: A history of the Dacha, 1710-2000. Ithaca, NY: Cornell University Press.

Mushketova, Anna. 1925. Letter of attorney, March 17. Mikkeli Provincial Archives in Finland.

Administrative Organ Archive Series Ea2.

Nevalainen, Pekka. 2003. Izgoi: rossiskie bezhentsy v Finliandii 1917-1939. St. Petersburg: Zhurnal Neva.

Newman, David, and Anssi Paasi. 1998. Fences and neighbours in a postmodern world: Boundary narratives in political geography. Progress in Human Geography 22 (2): 186-207.

Paasi, Anssi. 1996. Territories, boundaries, and consciousness: The changing geographies of the Finnish-Russian boundary. New York: J. Riley and Sons.

Pihkala, Kaarlo Uolevi. 1952. The Land Settlement Program of Finland. Land Economics 28 (2): 147-59.

Elsa Pukonen. 1959. Memoir manuscript. Folklore archives of the Finnish Literature Society. Series 61277.

Schukovnova, Maria. 1923. Letter of attorney, November 27. Mikkeli Provincial Archives in Finland. Administrative Organ Archive Series Ea2.

Stenius, Einar. 1923. Letter to Viipuri Province Governor's Office, October 16. Leningrad Oblast State Archive in Vyborg, Russia. F. 506, op.1, d.9, 1.140.

Supreme Court of Finland. 1925. Court decision on Sirki case, March 13. Leningrad Oblast State Archive in Vyborg, Russia. F.505, op.1, d.3, 1.13.

Viipuri Province Court of Appeals. 1926. Court decision on Kakko case, June 3. Mikkeli Provincial Archives in Finland. Administrative Organ Archive Series Ea2.

Viipuri Province Governor's Office. 1923. Memo No: 36266, August 24. Leningrad Oblast State Archive in Vyborg, Russia. F.505, op.7, d.17, 11.2-5.

Zahra, Tara. 2008. Kidnapped souls: National indifference and the battle for children in the Bohemian Lands 1900-1948. Ithaca, NY: Cornell University Press.

Zartman, William. 2010. Introduction: Identity, movement, and response. In Understanding life in the borderlands: Boundaries in depth and in motion, ed. William Zartman, 1-20. Athens: University of Georgia Press. 